This is a self-archived version of an original article. This version may differ from the original in pagination and typographic details.

Author(s): Martin, Maisa; Pajusalu, Renate

Title: Kirjoitusprosessi suurennuslasin alla

Year: 2020

Version: Published version

Copyright: (c) 2020 Kotikielen seura

Rights: In Copyright

Rights url: http://rightsstatements.org/page/InC/1.0/?language=en

Please cite the original version:

Martin, M., \& Pajusalu, R. (2020). Kirjoitusprosessi suurennuslasin alla. Virittäjä, 124(3), 438-

442. https://doi.org/10.23982/vir.91143 


\section{Kirjoitusprosessi suurennuslasin alla}

Olga Gaitšenja: Venekeelsete eesti keele oppijate kirjutamisprotsess. Tallinn: Tallinna ülikool 2019. 254 s. ISBN 978-9949-29466-4. Saatavilla verkossa osoitteessa http://www.digar.ee/id/nlib-digar:406495.

Kirjoittamista tarkastellaan tavallisimmin työn tuloksia tutkimalla. Valmiiseen tekstiin johtanut prosessi on pohjimmiltaan tutkijan ulottumattomissa, kirjoittajan mielessä. Kirjoittajaa voidaan tietenkin haastatella kesken kirjoittamisen tai sen jälkeen, mutta näin saatu tieto on aina kirjoittajan tietoisesti tai tiedostamatta suodattamaa, eikä omaa kirjoittamisprosessiaan ole helppo muistaa tai kuvailla. Ikkunoita prosessiin voidaan myös avata erilaisten teknisten välineiden avulla. Kirjoittajan aivojen toimintaa voidaan kuvantaa, mutta ainakin toistaiseksi on mahdotonta tietää, miten aivoissa havaitut ilmiöt tarkkaan ottaen liittyvät kirjoittamisen eri vaiheisiin. Tapahtumia aivoissa on liikaa, ja ne ovat päällekkäisiä. Myös katseen kohdistumista tekstiin voidaan seurata ja saada tietoa esimerkiksi siitä, milloin kirjoittaminen etenee lineaarisesti ja milloin taas palataan aiemmin kirjoitettuun. Tarkkaa tietoa kirjoittamisprosessista saadaan myös tietokoneohjelmilla, jotka jäljittävät näppäimistön painallukset. Näin saatuja tiedostoja voidaan sitten tarkastella monin eri tavoin.

Näppäintoimintojen tallennusta on hyödyntänyt Olga Gaitšenja toisella kielellä kirjoittamista koskevassa väitöskirjassaan, joka tarkastettiin Tallinnan yliopiston humanistisessa tiedekunnassa elokuussa 2019. Se koostuu neljästä artikkelista ja laajasta (115 s.) johdantoluvusta.
Artikkeleista yksi on julkaistu englanniksi ja muut kolme sekä johdanto viroksi. Kohdekielenä on viro, ja tutkimukseen osallistuneiden kirjoittajien ensikieli on venäjä. Kaikki 34 kirjoittajaa ovat Tallinnan yliopiston opiskelijoita. Viron opinnoissa pitemmällä olleille $(\mathrm{N}=17)$ annettiin tehtäväksi kirjoittaa argumentoiva teksti siitä, onko korkeakouluopiskelu tarpeen kaikille. Alemmalla tasolla opiskelevat $(\mathrm{N}=17)$ laativat kertovan tekstin siitä, mitä yliopisto on heille antanut. Ulkopuoliset kokeneet arvioijat sijoittivat kirjoitelmat Eurooppalaisen viitekehyksen (2007) taitotasoille (A2-C1).

\section{Näppäintoimintojen tallennus menetelmänä}

Gaitšenjan tutkimuksessa käytettiin meneillään olevan kirjoittamisprosessin tarkasteluun tarkoitettua Scriptlogohjelmaa, joka on suunniteltu Lundin yliopistossa vuosituhannen vaihteessa (ks. esim. Strömqvist \& Karlsson 2002). Ohjelmaa on sittemmin kehitelty edelleen monin tavoin. Nykyisin voidaan esimerkiksi yhdistää Scriptlog ja katseen kohdistumisen seurantalaitteet sekä ladata ohjelmaan kirjoitustehtäviä tai virikekuvia. Näppäintoimintojen jäljittämisen lisäksi ohjelma tuottaa tilastollista tietoa esimerkiksi kirjoittamisen nopeudesta ja taukojen määrästä ja pituudesta. Ohjelman avulla tutkija pääsee näkemään vaikkapa, onko kirjoittaja edennyt lineaarisesti vai myös muokannut aiemmin kirjoittamaansa. Kaikki siirtymät, poistot, lisäykset ja muutokset tulevat näkyviin. Scriptlog-dataa voidaan haluttaessa 
jälkeenpäin katsella yhdessä kirjoittajan kanssa ja näin kirvoittaa hänen muistikuviaan kirjoittamistapahtumasta.

Scriptlog ei suinkaan ole ainoa tutkimustarkoituksiin (ei siis esimerkiksi vakoiluun) suunniteltu näppäintoimintojen tallennusohjelma, mutta sitä kielentutkijat Suomessa ja Ruotsissa ovat eniten käyttäneet. Sen avulla on Suomessa tutkittu esimerkiksi ranskan oppijoiden (Mutta 2007) ja suomalaisten lasten kirjoittamista (Hintikka 2005). Pienessä sivuroolissa se on viron vaikutusta suomen sanaston ja rektioiden oppimiseen tutkivassa väitöskirjassa (Nissilä 2011), ja sitä on käytetty myös kerättäessä aineistoa aikuisilta suomalaisilta ruotsin ja englannin opiskelijoilta sekä suomenoppijoilta (ks. esim. Mäntylä, Lahtinen \& Toropainen 2020). Turun yliopistossa on meneillään useitakin Scriptlogia hyödyntäviä kielenoppimisen tutkimuksia. Sitä on käytetty hieman myös kääntämisen tutkimuksessa (Volanen 2010) ja äidinkielen kirjoittamisen opetuksessa (esim. Laine 2019). Gaitšenjan työ on tiettävästi Virossa ensimmäinen näppäintoimintojen tallennusta hyödyntävä tutkimus. Työtä ohjasivat professorit Annekatrin Kaivapalu Tallinnan yliopistosta ja Åsa Palviainen Jyväskylän yliopistosta.

\section{Tutkimuksen tavoitteet, rakenne ja tulokset}

Väitöskirjan ensimmäinen artikkeli (Pastuhhova [Gaitšenja] 2011) on metodinen. Siinä tarkastellaan näppäintoimintojen tallennuksen mahdollisuuksia kirjoittamisen tutkimuksessa. Artikkeli esittelee kirjoitusprosessien tutkimisen tapoja ja välineitä sekä kansanvälisiä tutkimuksia. Esimerkkinä on tapaustutkimus, jossa Eurooppalaisen viitekehyksen tasoa $\mathrm{C} 1$ edustava venäjänkielinen kirjoittaja kirjoittaa viroksi. Mukana on tilastollisen tarkastelun lisäksi esimerkkejä ilmiöistä, joihin tällä menetelmällä päästään kä- siksi. Tällaisia ovat vaikkapa sanan korvaaminen toisella tai asioiden esitysjärjestyksen muutokset.

Gaitšenjan tutkimuksen muissa osissa kirjoitusprosessia tarkastellaan kielitaidon kehittymisen näkökulmasta. Kehittymistä taitotasolta toiselle tarkastellaan sekä sujuvuuden että erityyppisten ongelmien jakaumien kautta. Tutkimuskysymykset ovat seuraavat:

1. Mikä on ominaista viro toisena kielenä -kirjoittamisen prosessille, ja miten se vaihtelee taitotasolta toiselle?

2. Mikä aiheuttaa eniten vaikeuksia kirjoittamisessa, ja miten vaikeuksien jakauma muuttuu, kun taitotaso nousee? Millaiset korjaukset ovat ominaisia eri taitotasoille, ja mitä korjaukset kertovat kielenoppimisesta?

3. Mitkä indikaattorit ovat yhteydessä kirjoittamisen sujuvuuteen, ja mitä muutoksia on taitotasojen välillä?

Toisessa artikkelissa (Pastuhhova [Gaitšenja] 2015) verrataan niin sanottuja mikrokonteksteja taitotasoilla A2C1. Mikrokonteksteilla tarkoitetaan erilaisia näppäilytapahtumia, kuten taukoja, siirtymiä, poistoja, lisäyksiä ja korjauksia jaoteltuina esiintymispaikan mukaan (esim. sanan sisällä, sanojen välillä, keskeytymättömien kirjoitusjaksojen välillä jne.). Näitä analysoidaan esiintymätiheyden ja keston kannalta. Analyysi on hyvä esimerkki siitä, mitä Scriptlogin tyyppisillä ohjelmilla voidaan tehdä ja mihin ne taas eivät riitä. Siitä saa myös käsityksen siitä, miten valtavasti yksityiskohtiin paneutuvaa ja tarkkaa työtä tämäntyyppinen tutkimus vaatii.

Mikrokontekstien tarkastelu osoittaa, että toisella kielellä kirjoittamisen prosessi on luonteeltaan jatkuvasti keskeytyvä ja sisältää paljon korjailua jopa ylimmilläkin taitotasoilla. Taitotasojen väliset erot eivät ole yllättäviä vaan noudattelevat sitä, mitä voisi olettaa aiemmin toisella 
kielellä kirjoitettujen tuotosten tutkimuksen perusteella, mutta tutkimuksen vahvuus on siinä, että erot saadaan näkyviin kirjoitusprosessin tasolla. Tasojen $\mathrm{B}_{2}$ ja $\mathrm{C} 1$ erojen indikaattorit ovat erityisen kiinnostavia kirjoittamisen kehityksen näkökulmasta.

Kolmas artikkeli (Pastuhhova [Gaitšenja] 2016) keskittyy korjauksiin. Artikkelissa esitellään selkeästi ja kattavasti monia tapoja luokitella korjauksia ennen kuin siirrytään oman aineiston korjausten kategorisointiin. Artikkelissa ei (ehkä merkkimäärän rajoitusten vuoksi) ole juuri esimerkkejä, joten lukijan voi olla vaikea hahmottaa erityyppisten korjausten laatua ja eroja, mutta onneksi aineistoesimerkkejä on lisätty johdantoartikkeliin. Erityisesti on nostettu esiin niin sanottuja konseptuaalisia eli sisällöllisiä korjauksia, jotka varmaan onkin vaikein luokitella. Muilta osin lukija joutuu enemmän kuvittelemaan kategorioiden nimien perusteella, millaisista korjauksista on kyse. Tutkimuksen tiukasta prosessiorientaatiosta kertoo se, että korjausten tuloksiin ei oteta lainkaan kantaa: tämän tutkimuksen kannalta on samantekevää, johtavatko korjaukset kohdekielenmukaiseen vai -vastaiseen ilmaukseen.

Neljännen artikkelin (Pastuhhova [Gaitšenja] 2017) aiheena on sujuvuus. Tämä vaikeasti määriteltävä käsite liitetään monesti suullisen kielitaidon kehitykseen, mutta sitä on pyritty kuvaamaan myös kirjoittamisen osalta, onhan se yksi kolmesta kielitaidon kehityksen keskeisestä CAF-dimensiosta kompleksisuuden ja tarkkuuden ohella (complexity, accuracy, fluency). Artikkelin alussa esitelläänkin kirjoitussujuvuuden määritelmiä ja mittareita sekä ensikielen että toisen kielen tutkimuksessa. Tähän tutkimukseen on valittu sujuvuuden indikaattoreista lineaarinen sujuvuus eli merkkimäärä minuutissa, keskeytymättömän kirjoitusjakson (writing burst) pituus, tällaisen jakson sisäinen sujuvuus ja koko tuotoksen sujuvuus eli lopullisen tekstin merkkimäärä minuuttia kohti. Tulokset osoittavat, että kaikki indikaattorit kasvavat melko tasaisesti taitotasolta toiselle.

\section{Kirjoittaminen osana toisen kielen oppimista}

Tutkimuksen teoreettista taustaa esitellään osin artikkeleissa mutta laajemmin johdannossa. Pääosassa ovat yleiset kirjoittamisen mallit, joita vertaillaan melko yksityiskohtaisesti. Ne taas hyödyntävät työmuistin käsitettä, joten myös sen tutkimusta käsitellään aika laajasti. Kaiken kaikkiaan tämä taustaosuus kertoo laajasta lukeneisuudesta ja perehtyneisyydestä kirjoittamisen tutkimukseen. Ohuemmaksi jää mallien yhteys valittuun menetelmään. Kysymys siitä, mistä teoretisoidun kirjoitusprosessin osasta tai konstruktista näppäintoimintojen tallennus parhaiten tuottaa empiiristä tietoa, ei saa vastausta. Gaitšenjalla olisi kuitenkin tämän kysymyksen pohdiskeluun oivat edellytykset, joten voi toivoa, että hän ryhtyy siihen myöhemmin.

Vaikka kaikki tutkimuskysymykset sisältävät kielitaidon kehityksen näkökulman, tähän liittyvää teoreettista taustaa on mukana hyvin niukasti. Eurooppalaisen viitekehyksen kirjoittamisen taitotasojen kuvaukset ovat tietenkin mukana, sillä aineisto on luokiteltu niiden perusteella, mutta ne esitellään annettuina, problematisoimatta. Tulee myös selväksi, että työ sijoittuu kognitiivisen toisen kielen oppimisen viitekehykseen, mutta tarkemmin ei työn pohjana olevaa omaa kieli- tai kielenoppimiskäsitystä avata. Toisen kielen oppimisen alalla keskeinen CAF-triadi mainitaan ja oman työn yhteys siihen osoitetaan sujuvuuden osalta. Tarkkuuden kehitys on mahdollista lisätä myöhemmin mukaan, kuten Gaitšenja ehdottaakin, sillä korjausten tulokset ja aineiston tekstien yleinen kohdekielen- 
omaisuus ovat tietenkin selvitettävissä, samoin kuin kompleksisuus ainakin joillakin mittareilla.

Tutkimuskysymyksiin saadaan pääpiirteissään riittävät vastaukset. Kommunikatiiviset taitotasot erottuvat toisistaan eri tavoin eri muuttujien valossa, kuten voi odottaakin. Artikkeleiden tulokset on koostettu selkeäksi taulukoksi, ja sitä on lisäksi avattu listaamalla eri taitotasoille tyypilliset piirteet. Alempien tasojen väliset muutokset näyttävät olevan selvemmin sidoksissa kielitaidon määrälliseen kasvuun, kun taas tasojen $\mathrm{B}_{2}$ ja $\mathrm{C}_{1}$ välinen muutos näyttää olevan enemmän laadullinen. Tutkimuskysymyksen 2 loppuosa mitä korjaukset kertovat kielenoppimisesta - jää kuitenkin ilmaan, sillä Gaitšenja välttää huolellisesti spekuloimasta, onko prosessitutkimuksen tuloksilla yhteyttä tutkimustuloksiin, jotka on saatu tarkastelemalla toisella kielellä kirjoittamisen tuotoksia. Tällaista tietoa kuitenkin on olemassa hieman vironkin osalta (esim. Kitsnik 2018), ja vertailu suomen kielen oppimisen tutkimuksiin olisi myös mahdollista. Tässä olisikin mainio tilaisuus yhteistyöhön virolaisten ja suomalaisten tutkijoiden välillä, sillä samantyyppisiä ja samoin perustein luokiteltuja aineistoja on olemassa molemmista kielistä.

Gaitšenjan tutkimustulokset ovat kiinnostavia toisella kielellä ja miksei ensikielelläkin kirjoittamisen kehityksen kansainväliselle tutkijayhteisölle. Ne olisi siis syytä saada julki myös englanniksi. Monissa hankkeissa eri maissa pyritään yhdistämään Eurooppalaisen viitekehyksen kommunikatiivista näkökulmaa ja kielellisten resurssien ja niiden käytön kehitystä. Tätä tutkimuslinjaa olisi jatkossa syytä edistää yhdessä muilla tavoin kirjoittamisen kehitystä tutkivien kanssa, sillä näyttää siltä, että prosessija produktitutkimuksen tulokset voisivat yhdessä antaa nykyistä paljon tarkemman kuvan siitä, miten toisen kielen kirjoitustaito kehittyy.
MaISA MARTIN

etunimi.sukunimi@jyu.fi

Renate Pajusalu

etunimi.sukunimi@ut.ee

Maisa Martin on Jyväskylän yliopiston kielten ja viestinnän laitoksen suomi toisena kielenä -alan emeritaprofessori. Renate Pajusalu on yleisen kielitieteen professori Tarton yliopiston viron ja yleisen kielitieteen laitoksessa.

\section{Lähteet}

Eurooppalainen viitekehys $2007=$ Euroopa keeleõppe raamdokument. Õppimine, ópetamine ja hindamine. Tartu: Haridusja Teadusministeerium.

Hintikka, Terhi 2005: Maahanmuuttajalapset avaruusseikkailua kirjoittamassa. Kirjoitusprosessin analyysi. Suomen kielen pro gradu -tutkielma. Jyväskylän yliopisto. https://jyu.finna.fi/Record/jykdok.982933 (24.4.2020).

KITSNIK, MARE 2018: Iga asi omal ajal. Eesti keele B1- ja B2-taseme verbikonstruktioonik keeleoskuse arengu näitajana. Väitöskirja. Tallinna: Tallinnan yliopisto.

LAINE, PäIVI 2019: Nuoret ovat taitavia analysoimaan omaa kirjoittamistaan. Suomen kielen seuran blogi. https:// suomenkielenseura.fi/nuoret-ovattaitavia-analysoimaan-omaa-kirjoittamistaan/.

Mutta, MaArit 2007: Un processus cognitif peut en cacher un autre. Étude de cas sur laisance rédactionnelle des scripteurs $f i$ nnophones et francophones. Annales universitatis turkuensis. Série B 300. Turku: Turun yliopisto 2007.

Mäntylä, Katja - Lahtinen, Sinikka - Toropainen, Outi 2020: Processing L2 vocabulary in writing. - Paul Booth \& Jon Clenton (toim.), First language influences on multilingual lexicons s. 107-124. London: Routledge.

Nissilä, LeENA 2011: Viron kielen vaikutus suomen kielen verbien ja niiden rektioiden oppimiseen. Acta Universitatis Ouluensis B Humaniora 99. Oulu: Oulun yliopisto. 
http://urn.fi/urn:isbn:9789514296161.

Pastuhhova [Gaitšenja], Olga 2011:

Kirjaliku produtseerimisprotsessi uurimise võimalused programmi ScriptLog abil. Juhtumiuuring. - Lähivõrdlusi.

Lähivertailuja 21 s. 185-212.

- 2015: Using micro-contexts to describe a writing process in Estonian as a second language across proficiency levels. - Eesti Rakenduslingvistika Ühingu aastaraamat 11 s. 205-222.

_ 2016: Eesti keele kui teise keele kirjutamisprotsessi paranduste multidimensionaalne võrdlus keeleoskustasemeti. - $L \ddot{a}$ hivõrdlusi. Lähivertailuja 26 s. 385-425.
_ 2017: Eesti keele kui teise keele kirjutamisprotsessi sujuvuse võrdlus keeleoskustasemeti. - Eesti Rakenduslingvistika Ühingu aastaraamat 13 s. 107-122.

Strömqvist, Sven - Karlsson, HenRIK 2002: ScriptLog for Windows. User's Manual. Lund: Lunds universitet.

Volanen, Sanna 2010: What does the translator do when she takes a moment? A Scriptlog-aided analysis of long pauses and dictionary use in a translation process. Englannin kielen kandidaatintutkielma. Jyväskylän yliopisto. https:// jyx.jyu.fi/handle/123456789/38483 (24.4.2020).

\section{Slaavilaisen verbiaspektin vastineet suomessa: tilastollista näyttöä puola-suomi-puola-aineistosta}

\author{
Edyta Jurkiewicz-Rohrbacher: Polish \\ verbal aspect and its Finnish statisti- \\ cal correlates in the light of a parallel \\ corpus. Helsingin yliopisto 2019. \\ 274 s. ISBN 978-951-51-5157-5. Saata- \\ villa verkossa osoitteessa http://urn.fi/ \\ URN:ISBN:978-951-51-5158-2.
}

Edyta Jurkiewicz-Rohrbacher tutkii väitöskirjassaan puolan kielen verbiaspektia ja vertailee sitä suomen kielessä tarjolla oleviin aspektin ilmaisukeinoihin: kokonais- ja osaobjektin valintaan, latiivi- vs. essiivisijaisiin määreisiin ja verbijohdoksiin. Kontrastiivisen tarkastelun lisäksi kunnianhimoisena tavoitteena on uudelleenarvioida puolan verbiaspektin merkityssisältöä ja yleisemmin teoreettisena pyrkimyksenä uudistaa kieltenvälisessä vertailussa käytettävää aspektin määritelmää (s. 5). Otteeltaan deskriptiivinen ja korpuslingvistinen tutkimus pohjautuu perimmältään Harrisin (1954) distribuutiohypoteesiin, ja aineistona on tarkasti rajattu kaksikielinen ja -suuntainen rinnakkaiskorpus. Jurkiewicz-Rohrbacherin tutkimusta voidaan pitää uraauurtavana työnä, joka havainnollistaa korpustutkimuksen hyötyjä kontrastiivisessa kielitieteessä.

Nykyaikaiset korpuspohjaiset lähestymistavat tuottavat uutta tietoa kysymyksistä, joita on aikaisemmin voitu tutkia vain suppeahkolla aineistolla perinteisin menetelmin. Verbiaspekti on ollut slavistiikan keskeisiä tutkimuskohteita, ja aspektisemantiikka on jo pitkään kiinnostanut myös muiden kielten tutkijoita ja typologeja. Korpuspohjaisia vertailevia tutkimuksia on kuitenkin tehty vähän, koska sopivia monikielisiä korpuksia ei juuri ole ollut saatavilla. ${ }^{1}$ Jurkiewicz-Rohrbacher

1. On kyllä olemassa suuria rinnakkaiskorpuksia, jotka koostuvat joko hyvin vanhoista teksteistä (Raamatusta, 1800-luvun kaunokirjallisuudesta ja vanhoista käännöksistä), erikoiskielisistä teksteistä (kansainvälisistä sopimuksista, tietokoneohjelmien oppaista) tai suppeista tekstilajeista 